\title{
ANALYSIS OF AN EXTRATROPICAL CYCLONE IN THE SOUTHWEST ATLANTIC: WRF MODEL BOUNDARY CONDITIONS SENSITIVITY
}

\author{
L. R. Diaz ${ }^{1, *}$, R. A. Mollmann Junior ${ }^{1}$, G. B. Muchow ${ }^{1}$, P. S. Käfer ${ }^{1}$, N. S. Rocha ${ }^{1}$, E. A. Kaiser ${ }^{1}$, S. T. L. Costa ${ }^{1}$, G. P. Hallal ${ }^{1}$ \\ R. C. M. Alves ${ }^{1}$, S. B. A. Rolim ${ }^{1}$ \\ ${ }^{1}$ State Research Center for Remote Sensing and Meteorology (CEPSRM), Universidade Federal do Rio Grande do Sul (UFRGS), \\ Porto Alegre, Brazil - (lucas.diaz, gabrielbm, najila.rocha, rita.alves, silvia.rolim)@ufrgs.br; (mollmannr, pamelaskafer, \\ savannahlemos95, gabrielhallal)@gmail.com; kaiser-eduardo@ hotmail.com
}

KEY WORDS: WRF, Sensitivity analysis, Extratropical cyclones, NCEP FNL, NCEP CFSv2

\begin{abstract}
:
Meteorological conditions characterize the southern Brazilian coast a cyclogenetic area. The current study seeks to analyse the sensitivity of the WRF model to initial and boundary meteorological conditions in the simulation of an extratropical cyclone that occurred on the southern Brazilian coast on October 28, 2018. For this purpose, the WRF model was set up for two experimental simulations using the NCEP FNL and the NCEP CFSv2 reanalysis data as initial/boundary conditions. The sensitivity analysis was carried out with the cyclone trajectory assessment and comparison with wind speed data from meteorological stations. The results show that the initial meteorological conditions significantly influence the simulation of the cyclone track. In a nutshell, the use of NCEP CFSv2 resulted in more accurate wind speed simulations when compared to the values observed in the stations. With correlation coefficient values around 0.7 , and the lowest bias $(-2.57 \mathrm{~m} / \mathrm{s})$ and RMSE $(3.68 \mathrm{~m} / \mathrm{s})$. In contrast, using the NCEP FNL data, the lowest correlation coefficient and the highest bias and RMSE values were obtained: $0.58,-3.97 \mathrm{~m} / \mathrm{s}$ and $4.91 \mathrm{~m} / \mathrm{s}$, respectively. However, both simulations tend to underestimate observational wind speed values. The superior performance of simulations using CFSv2 tends to be related to the finer horizontal resolution of this reanalysis data source.
\end{abstract}

\section{INTRODUCTION}

Meteorological conditions in the southern Brazilian coast characterize this region as a cyclogenetic area where extratropical cyclones are formed (Hoskins and Hodges, 2005; Pezzi et al., 2016b; Sutil et al., 2019). These extratropical cyclones are usually associated with severe weather conditions. With strong winds and intense precipitation these events can pose a threat to life and heritage and may cause major damage to the impacted regions (Bitencourt et al., 2011; Dal Piva et al., 2008; Parise et al., 2009; Pezzi et al., 2016a).

However, despite the risks and importance of studying the dynamic processes involved in cyclogenesis events, Pezzi et al. (2016a) and Dal Piva et al. (2008) report that there is a lack of studies on cyclogenesis on the east coast of South America that allow a greater understanding of the phenomena that relate the state of the ocean and the atmosphere in this region. Likewise, Sutil et al. (2019) state that this small number of studies is mainly related to the difficulty of obtaining in situ atmospheric and oceanographic data.

In this context, remote sensing data and atmospheric numerical models can be an interesting tool for studying the dynamic processes involved in cyclogenesis events (Dal Piva et al., 2008; Mendonça et al., 2017; Pullen et al., 2017; Ricchi et al., 2017; Sutil et al., 2019). The Weather Research and Forecasting (WRF) model is a numerical weather prediction and atmospheric simulation system designed for both research and operational application (Skamarock et al., 2008). This mesoscale model allows different physical and numerical options to be applied to a set of atmospheric/geographic scales (González-Alonso de Linaje et al., 2019; Skamarock et al.,
2008; Wang et al., 2017). Due to these and other capabilities, the WRF model has been commonly used in recent decades to simulate a wide range of phenomena (Feng et al., 2019; Fernández-González et al., 2018; Hari Prasad et al., 2017; Jandaghian et al., 2018; Martínez-Castro et al., 2019; Skamarock et al., 2008; Vijaya Kumari et al., 2019; Wang et al., 2017; Zhang et al., 2017). Nevertheless, the quality of initial and boundary conditions is a key for accurate cyclones (occurrence and development) simulation (Chutia et al., 2019; Davolio et al., 2009; Mylonas et al., 2019; Ricchi et al., 2017; Zhang et al., 2017).

Based on the above exposed, this study aims to analyse the sensitivity of the WRF model to two different reanalysis data sources, used as initial and boundary conditions, in the simulation of an extratropical cyclone occurred on the southern Brazilian coast on October 28, 2018. We performed two simulations using as initial and boundary conditions the National Centers for Environmental Prediction (NCEP) FNL (Final) Operational Global Analysis (NCEP et al., 2000) data and the NCEP Climate Forecast System Version 2 (CFSv2) (Saha et al., 2014) reanalysis data. The structure of this paper is arranged as follows: in Section 2, the data and methods used are described. The results are presented and discussed in Sections 3. Section 4 reiterated the conclusions of the study.

\section{MATERIALS AND METHODS}

\subsection{WRF Configuration}

The WRF model, version 3.9.1., was configured for two experimental simulations of a meteorological event that occurred between October 21 and 28, 2018. Both experiments

\footnotetext{
* Corresponding author
} 
presented the same configurations, differing only in relation to the input meteorological data. As mentioned above, the two data sources used as initial and boundary conditions were the NCEP FNL and the NCEP CFSv2. The NCEP FNL data are on $1^{\circ} \times 1^{\circ}$ grids prepared operationally every six hours $(00,06,12$, and 18 UTC), from 1999 to the present. This product is provided from the Global Data Assimilation System (GDAS). The dataset is scaled to 26 mandatory levels, from $1000 \mathrm{hPa}$ to $10 \mathrm{hPa}$ (NCEP et al., 2000). Whereas the NCEP CFSv2 reanalysis data are arranged in grids with various horizontal resolutions $\left(0.2^{\circ}, 0.5^{\circ}, 1.0^{\circ}\right.$, and $\left.2.5^{\circ}\right)$ for the 6-hourly atmospheric, oceanic and land surface analyzed products. Also initialized four times a day (00, 06, 12, and 18 UTC), the CFSv2 is available from January 2011 to the present and in 37 vertical (pressure) levels (1000 to 1 mbar) (Saha et al., 2014).

The simulations were both made from two domains in two-way nesting mode. The grids were formatted with a ratio of $1: 4$. Domain 1 (D01) was configured with spatial resolution of 20 $\mathrm{km}$ while Domain 2 (D02), from which the results of this study were extracted, was configured with a resolution of $5 \mathrm{~km}$ (Figure 1). Table 1 presents the main simulations configurations in the both domains, including the physical parameterizations used.

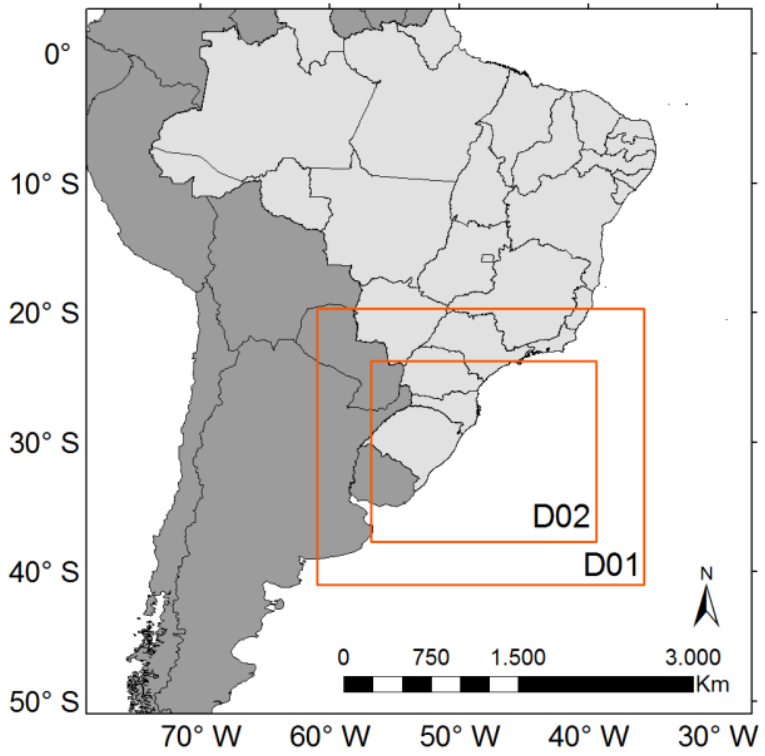

Figure 1. Model domains utilized in the WRF simulations.

\begin{tabular}{|l|c|c|}
\hline & Domain 1 & Domain 2 \\
\hline $\begin{array}{l}\text { Spatial } \\
\text { Resolution }\end{array}$ & $20 \mathrm{~km}$ & $5 \mathrm{~km}$ \\
\hline $\begin{array}{l}\text { Temporal } \\
\text { Resolution }\end{array}$ & 3 hours & 1 hours \\
\hline $\begin{array}{l}\text { Cloud } \\
\text { Microphysics }\end{array}$ & WRF Double-Moment 6-Class (Lim and \\
\hline $\begin{array}{l}\text { Shortwave } \\
\text { Radiation }\end{array}$ & Dudhia Shortwave Scheme (Dudhia, 1989) \\
\hline $\begin{array}{l}\text { Longwave } \\
\text { Radiation }\end{array}$ & $\begin{array}{c}\text { RRTM Longwave Scheme (Mlawer et al., } \\
\text { 1997) }\end{array}$ \\
\hline $\begin{array}{l}\text { Land-Surface } \\
\text { Model }\end{array}$ & $\begin{array}{c}\text { Unified NOAH Land Surface Model } \\
\text { (Tewari et al., 2004) }\end{array}$ \\
\hline Surface Layer & $\begin{array}{l}\text { Revised MM5 Scheme } \\
\text { (Jiménez et al., 2012) }\end{array}$ \\
\hline
\end{tabular}

\begin{tabular}{|l|c|c|}
\hline $\begin{array}{l}\text { Planetary } \\
\text { Boundary } \\
\text { Layer }\end{array}$ & \multicolumn{2}{|c|}{$\begin{array}{c}\text { Yonsei University } \\
\text { (Hong et al., 2006) }\end{array}$} \\
\hline \multirow{4}{*}{ Cumulus } & Grell 3D Ensemble & Grell 3D Ensemble \\
& Scheme (Grell, & Scheme (Grell, \\
& 1993; Grell and & 1993; Grell and \\
& Dévényi, 2002) & Dévényi, 2002) \\
\hline
\end{tabular}

Table 1. Simulation main configurations for both domains.

\subsection{Evaluation of the Simulations}

In order to evaluate the simulations and the sensitivity of boundary meteorological conditions, an analysis of the extratropical cyclone trajectory was performed, focused on 24 hours (05 to 05 UTC) between October 27 and 28, 2018. The extratropical cyclone trajectory (cyclone tracking) was extracted using minimum Sea Level Pressure (SLP) points from the two WRF simulations (Domain 2), with NCEP FNL and NCEP CFSv2 boundary conditions. In addition, European Centre for Medium-Range Weather Forecasts (ECMWF) ReAnalysis 5 (ERA5) reanalysis data (ECMWF, 2019) were also included in the cyclone trajectory analysis for comparison purposes.

ERA5 is the fifth generation of ECMWF atmospheric reanalysis and is being developed through the Copernicus Climate Change Service (C3S). This dataset has a spatial horizontal resolution of $31 \mathrm{~km}$, approximately, with 137 hybrid sigma/pressure (model) levels in the vertical, with the top level at $0.01 \mathrm{hPa}$ - which are interpolated to 37 vertical pressure levels. ERA5 is currently available for the period 1979 to the present and the data are, generally, available at an hourly frequency.

Furthermore, seeking to assess the performance of the simulations, the model results were compared with observational field data of meteorological stations. We selected three automatic meteorological stations from the Brazilian National Institute of Meteorology (INMET) located in the cities of: Mostardas $(-31.25,-50.91)$, Tramandaí $(-30.01,-50.14)$ and Torres $(-29.35,-49.73)$. The location of the stations can be seen in Figure 2. The variables used in this analyze were the wind speed at 10 meters for the WRF model simulations and wind gust speed for the stations, hourly between October 24 and 28, 2018.

\section{RESULTS AND DISCUSSION}

\subsection{Cyclone Trajectory Analysis}

Figure 2 shows the trajectory of the extratropical cyclone. It compares the paths extracted from the WRF simulations, using NCEP FNL and NCEP CFSv2 as initial conditions, and the ERA5 reanalysis data. 


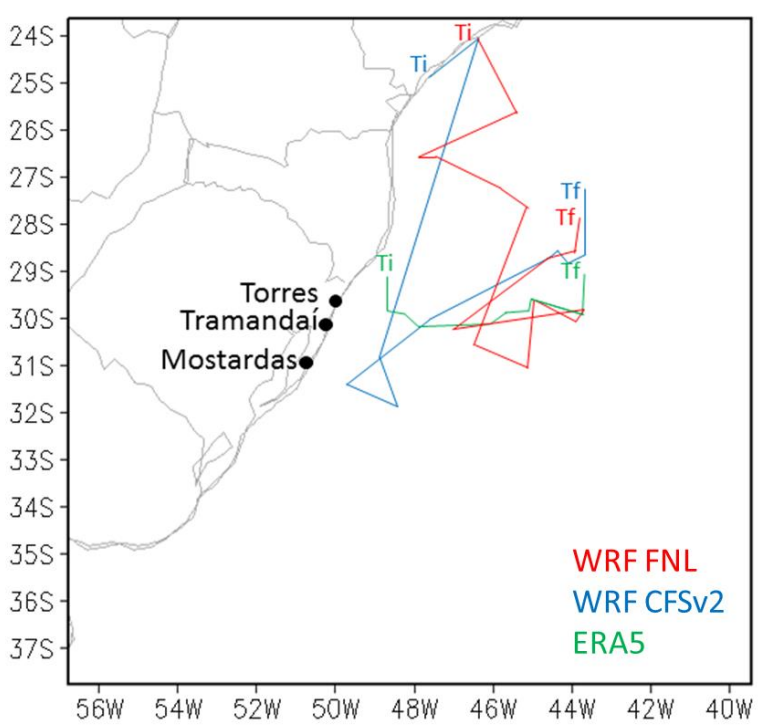

Figure 2. Cyclone trajectory between October 27 at $05 \mathrm{UTC}(\mathrm{Ti})$ and October 28 at 05 UTC $(T f)$. The points indicate the location of the meteorological stations.

It can be observed the difference that the change in the initial and boundary conditions causes in the cyclone simulated path. The variations are even greater when comparing the trajectories extracted from the simulations (WRF FNL and WRF CFSv2) with those extracted from the ERA5. It is important to note that the ERA5 SLP data are directly from reanalysis $\left(0.25^{\circ}\right.$ resolution grid), whereas in WRF FNL and WRF CFSv2 the reanalysis data with horizontal resolutions of $1^{\circ}$ and $0.25^{\circ}$, respectively, has been refined to $5 \mathrm{~km}$ grids through WRF model.

Moreover, the results also show that in $T i$ the simulated minimum SLP centre were near the coast of São Paulo State, before the cyclone formation on the coast of Rio Grande do Sul State - which is where the analyses are focused. On the other hand, near the $T f$ the simulated minimum SLP centres are located next to each other. Being even close to ERA5, unlike in $T i$ when the minimum pressure values simulated by the WRF model are relatively distant from those extracted from ERA5.

\subsection{Wind Speed Analysis}

Aiming to illustrate the results of the simulations and the spatialization of wind speed values during the passage of the extratropical cyclone, Figure 3 shows the wind speed and direction at 10 meters at 17 UTC on October 27, 2018, extracted from the Domain 2 of the WRF simulations using NCEP FNL and NCEP CFSv2 as initial conditions.
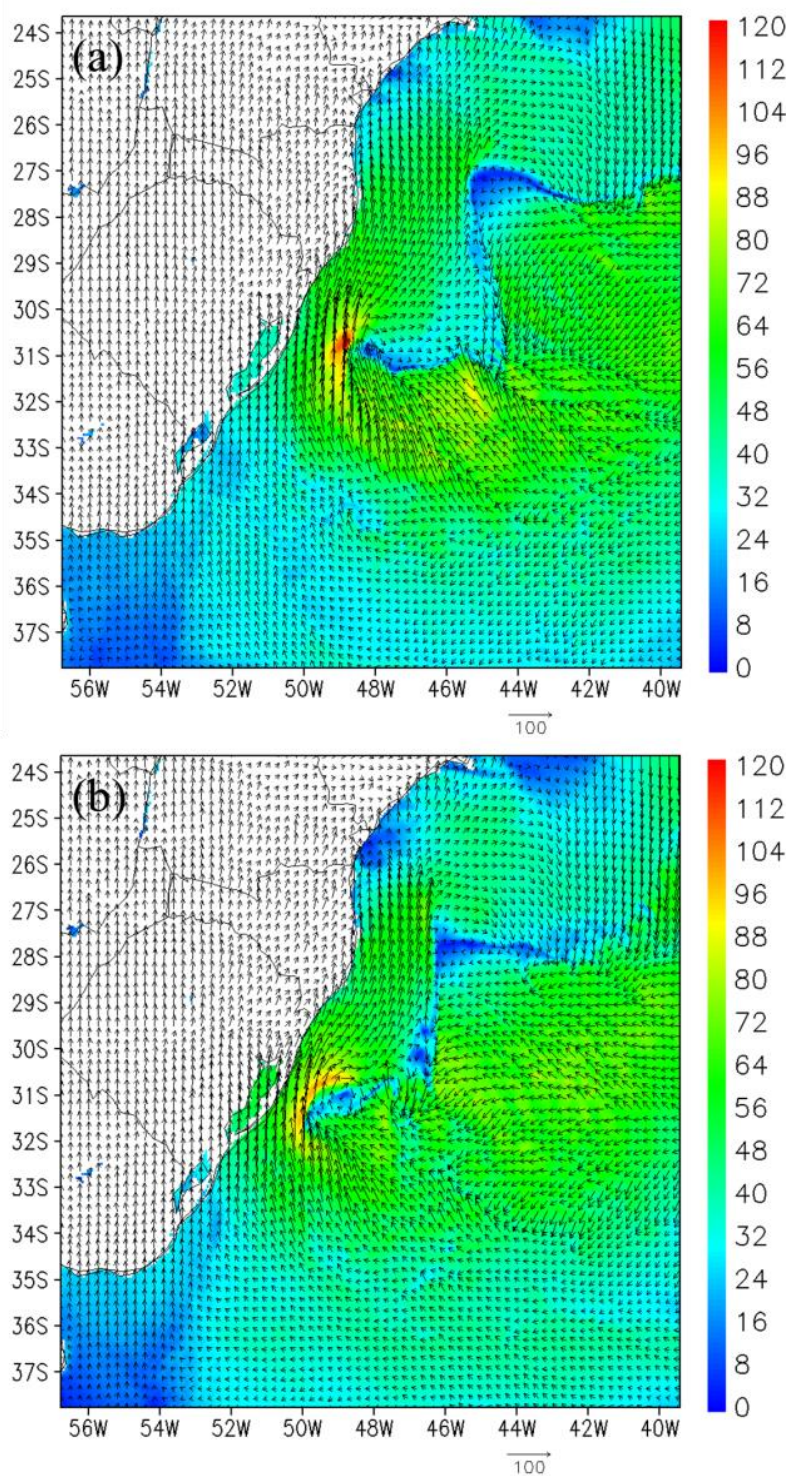

Figure 3. Wind speed $(\mathrm{Km} / \mathrm{h})$ and direction at 10 meters at 17 UTC on October 27, 2018. WRF simulations using NCEP FNL

(a) and NCEP CFSv2 (b) as initial conditions.

To quantify and evaluate the simulations, the wind speed values resulting from the WRF were compared with in situ observational data from INMET meteorological stations. This comparison is presented in Figure 4, with hourly wind speed values $(\mathrm{m} / \mathrm{s})$ between October 24 and 28, 2018. The quantification of this comparison was made by calculating the statistical metrics correlation coefficient (R), bias and Root Mean Square Error (RMSE). The results of the statistical analysis are presented in Table 2 . 


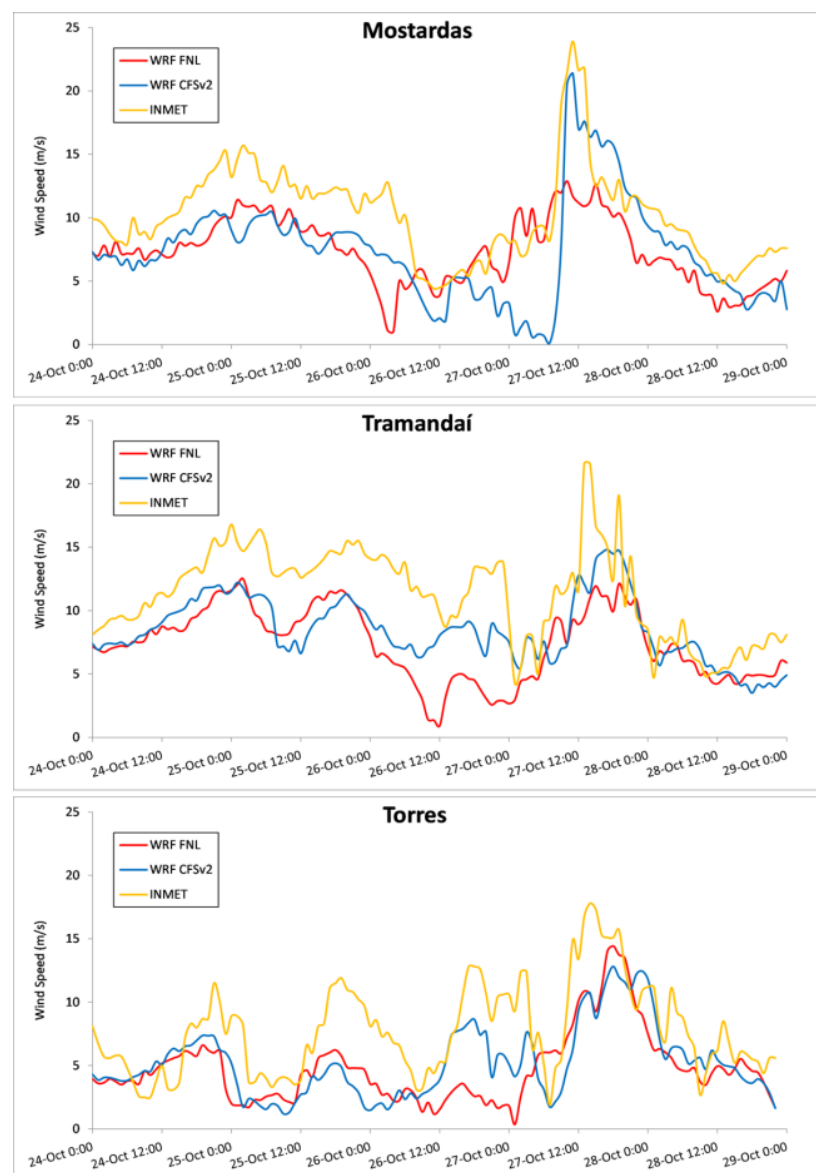

Figure 4 . Wind speed $(\mathrm{m} / \mathrm{s})$ at 10 meters from WRF FNL (red line) and WRF CFSv2 (blue line) and wind gust speed (m/s) from INMET stations (yellow line), between October 24 and 28, 2018.

\begin{tabular}{|c|c|c|c|}
\hline & & WRF FNL & WRF CFSv2 \\
\hline \multirow{3}{*}{ 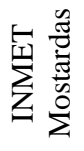 } & $\mathrm{R}$ & 0.68 & 0.79 \\
\hline & $\operatorname{Bias}(\mathrm{m} / \mathrm{s})$ & -2.85 & -2.82 \\
\hline & $\operatorname{RMSE}(\mathrm{m} / \mathrm{s})$ & 3.92 & 3.77 \\
\hline \multirow{3}{*}{ 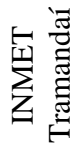 } & $\mathrm{R}$ & 0.61 & 0.74 \\
\hline & Bias $(\mathrm{m} / \mathrm{s})$ & -3.97 & -2.85 \\
\hline & $\operatorname{RMSE}(\mathrm{m} / \mathrm{s})$ & 4.91 & 3.72 \\
\hline \multirow{3}{*}{ 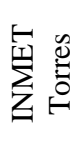 } & $\mathrm{R}$ & 0.58 & 0.69 \\
\hline & Bias $(\mathrm{m} / \mathrm{s})$ & -3.01 & -2.57 \\
\hline & $\operatorname{RMSE}(\mathrm{m} / \mathrm{s})$ & 4.26 & 3.68 \\
\hline
\end{tabular}

Table 2. Statistical metrics comparing the observed INMET stations wind speed with those simulated by the WRF model (FNL and CFSv2).

Note that there is an average tendency for simulated WRF wind speeds to underestimate what was observed by meteorological stations. This underestimation occurs in the three analysed stations. Most significant when NCEP FNL reanalysis data are used as initial conditions. In addition, WRF CFSv2 simulations showed a higher correlation with the in situ wind speed data. For RMSE, initial conditions using NCEP CFSv2 outperformed NCEP FNL. Since the highest RMSE values occurred for WRF FNL in all the three INMET stations.
It is important to observe that WRF CFSv2 has a tendency to simulate more accurately peak wind speed situations. As is the case of the 11 UTC on October 27 in Mostardas, which can be clearly seen in Figure 4 . This result could be explained by the fact that the initial/boundary conditions influenced in the location of the minimum SLP centre and the winds of the cyclone. In the simulations with CFSv2 the points of minimum SLP, and consequently the winds of greater intent, were located closer to the coast of Rio Grande do Sul State, where the analysed meteorological stations are installed. This can be perceived in Figure 2 and Figure 3.

In summary, the change in initial and boundary conditions affects both cyclone path and wind speed simulations. The better performance of WRF CFSv2 simulations tends to be due to the higher horizontal resolution of NCEP CFSv2 reanalysis data.

\section{CONCLUSIONS}

In the present paper, a sensitivity analysis of WRF-ARW model initial and boundary meteorological conditions was set up and evaluated for a cyclogenesis event in the southern Brazilian coast. The simulations encompassing an extratropical cyclone occurred on October 28, 2018 were performed with two different reanalysis data sources as initial/boundary conditions. This data sources were the NCEP FNL and the NCEP CFSv2. The performance of the simulations and the role of the initial/boundary conditions were evaluated by cyclone tracking analysis and comparisons of wind speed values with observational data from meteorological stations.

The results showed that the differences in initial/boundary conditions impact the simulation of the cyclone trajectory. The differences between the simulated tracks WRF FNL and NCEP CFSv2 were significant. Compared to the track extracted from ERA5, the differences were even greater. In addition, as far as comparative analysis, both simulations underestimated (average tendency) the wind speed values observed in the three stations. This underestimation is higher for WRF FNL, with a maximum negative bias of $-3.97 \mathrm{~m} / \mathrm{s}$ for Tramandaí INMET station. WRF CFSv2 wind speed values showed a higher correlation with those from INMET stations, with acceptable correlation coefficient (R) values ranging from 0.69 to 0.79 . Simulations with CFSv2 also presented lower RMSE values in all stations, with a minimum of $3.68 \mathrm{~m} / \mathrm{s}$ in Torres. On the other hand, the maximum RMSE occurred at Tramandaí station in the simulation with FNL, $4.91 \mathrm{~m} / \mathrm{s}$. Therefore, we conclude that the use of NCEP CFSv2 reanalysis data as initial and boundary conditions showed a better performance in the wind speed simulation, compared to the use of NCEP FNL. This found can be considered as expected due to CFSv2 higher horizontal resolution $\left(0.25^{\circ}\right.$ against $\left.1^{\circ}\right)$.

Future works could include others sensitivity experiments, testing a range of physics parameterization schemes, e.g., microphysics and planetary boundary layer schemes. Moreover, the use of remote sensing data like the Rapid Scan High Rate from SEVIRI could be used to derive the cyclone centre positions and improve the sensitivity analysis with regards to cyclone tracks validation.

\section{REFERENCES}

Bitencourt, D.P., Manoel, G., Acevedo, O.C., Fuentes, M.V., Muza, M.N., Rodrigues, M.L., Leal Quadro, M.F., 2011. 
Relating winds along the Southern Brazilian coast to extratropical cyclones. Meteorol. Appl. 18, 223-229. https://doi.org/10.1002/met.232

Chutia, L., Pathak, B., Parottil, A., Bhuyan, P.K., 2019. Impact of microphysics parameterizations and horizontal resolutions on simulation of "MORA" tropical cyclone over Bay of Bengal using Numerical Weather Prediction Model. Meteorol. Atmos. Phys. 131, 1483-1495. https://doi.org/10.1007/s00703-0180651-0

Dal Piva, E., Moscati, M.C. de L., Gan, M.A., 2008. Papel dos fluxos de calor latente e sensível em superfície associado a um caso de ciclogênese na Costa Leste da América do Sul. Rev. Bras. Meteorol. 23, 450-476. https://doi.org/10.1590/S010277862008000400006

Davolio, S., Miglietta, M.M., Moscatello, A., Pacifico, F., Buzzi, A., Rotunno, R., 2009. Numerical forecast and analysis of a tropical-like cyclone in the Ionian Sea. Nat. Hazards Earth Syst. Sci. 9, 551-562. https://doi.org/10.5194/nhess-9-551-2009

Dudhia, J., 1989. Numerical Study of Convection Observed during the Winter Monsoon Experiment Using a Mesoscale Two-Dimensional Model. J. Atmos. Sci. 46, 3077-3107. https://doi.org/10.1175/1520-

0469(1989)046<3077:NSOCOD>2.0.CO;2

ECMWF, 2019. ERA5 Reanalysis (0.25 Degree LatitudeLongitude Grid). https://doi.org/10.5065/BH6N-5N20

Feng, Y., Min, J., Zhuang, X., Wang, S., 2019. Ensemble Sensitivity Analysis-Based Ensemble Transform with 3D Rescaling Initialization Method for Storm-Scale Ensemble Forecast. Atmosphere (Basel). 10, 24. https://doi.org/10.3390/atmos10010024

Fernández-González, S., Martín, M.L., García-Ortega, E., Merino, A., Lorenzana, J., Sánchez, J.L., Valero, F., Rodrigo, J.S., 2018. Sensitivity analysis of the WRF model: Windresource assessment for complex terrain. J. Appl. Meteorol. Climatol. 57, 733-753. https://doi.org/10.1175/JAMC-D-170121.1

González-Alonso de Linaje, N., Mattar, C., Borvarán, D., 2019. Quantifying the wind energy potential differences using different WRF initial conditions on Mediterranean coast of $\begin{array}{lll}\text { Chile. Energy } & 116027 .\end{array}$ https://doi.org/10.1016/j.energy.2019.116027

Grell, G.A., 1993. Prognostic Evaluation of Assumptions Used by Cumulus Parameterizations. Mon. Weather Rev. 121, 764787. https://doi.org/10.1175/15200493(1993)121<0764:PEOAUB > 2.0.CO;2

Grell, G.A., Dévényi, D., 2002. A generalized approach to parameterizing convection combining ensemble and data assimilation techniques. Geophys. Res. Lett. 29, 38-1-38-4. https://doi.org/10.1029/2002GL015311

Hari Prasad, K.B.R.R., Srinivas, C.V., Rao, T.N., Naidu, C.V., Baskaran, R., 2017. Performance of WRF in simulating terrain induced flows and atmospheric boundary layer characteristics over the tropical station Gadanki. Atmos. Res. 185, 101-117. https://doi.org/10.1016/j.atmosres.2016.10.020
Hong, S.-Y., Noh, Y., Dudhia, J., 2006. A New Vertical Diffusion Package with an Explicit Treatment of Entrainment Processes. Mon. Weather Rev. 134, 2318-2341. https://doi.org/10.1175/MWR3199.1

Hoskins, B.J., Hodges, K.I., 2005. A New Perspective on Southern Hemisphere Storm Tracks. J. Clim. 18, 4108-4129. https://doi.org/10.1175/JCLI3570.1

Jandaghian, Z., Touchaei, A.G., Akbari, H., 2018. Sensitivity analysis of physical parameterizations in WRF for urban climate simulations and heat island mitigation in Montreal. Urban Clim. 24, 577-599. https://doi.org/10.1016/j.uclim.2017.10.004

Jiménez, P.A., Dudhia, J., González-Rouco, J.F., Navarro, J., Montávez, J.P., García-Bustamante, E., 2012. A Revised Scheme for the WRF Surface Layer Formulation. Mon. Weather Rev. 140, 898-918. https://doi.org/10.1175/MWR-D-1100056.1

Lim, K.-S.S., Hong, S.-Y., 2010. Development of an Effective Double-Moment Cloud Microphysics Scheme with Prognostic Cloud Condensation Nuclei (CCN) for Weather and Climate Models. Mon. Weather Rev. 138, 1587-1612. https://doi.org/10.1175/2009MWR2968.1

Martínez-Castro, D., Kumar, S., Flores Rojas, J.L., MoyaÁlvarez, A., Valdivia-Prado, J.M., Villalobos-Puma, E., Castillo-Velarde, C. Del, Silva-Vidal, Y., 2019. The Impact of Microphysics Parameterization in the Simulation of Two Convective Rainfall Events over the Central Andes of Peru Using WRF-ARW. Atmosphere (Basel). 10, 442. https://doi.org/10.3390/atmos10080442

Mendonça, L.F., Souza, R.B., Aseff, C.R.C., Pezzi, L.P., Möller, O.O., Alves, R.C.M., 2017. Regional modeling of the water masses and circulation annual variability at the Southern Brazilian Continental Shelf. J. Geophys. Res. Ocean. 122, 1232-1253. https://doi.org/10.1002/2016JC011780

Mlawer, E.J., Taubman, S.J., Brown, P.D., Iacono, M.J., Clough, S.A., 1997. Radiative transfer for inhomogeneous atmospheres: RRTM, a validated correlated-k model for the longwave. J. Geophys. Res. Atmos. 102, 16663-16682. https://doi.org/10.1029/97JD00237

Mylonas, M.P., Douvis, K.C., Polychroni, I.D., Politi, N., Nastos, P.T., 2019. Analysis of a Mediterranean Tropical-Like Cyclone. Sensitivity to WRF Parameterizations and Horizontal Resolution. Atmosphere (Basel). 10, 425. https://doi.org/10.3390/atmos10080425

NCEP, National Weather Service, NOAA, U.S. Department of Commerce, 2000. NCEP FNL Operational Model Global Tropospheric Analyses, continuing from July 1999. Research Data Archive at the National Center for Atmospheric Research, Computational and Information Systems Laboratory. https://doi.org/10.5065/D6M043C6

Parise, C.K., Calliari, L.J., Krusche, N., 2009. Extreme storm surges in the south of Brazil: Atmospheric conditions and shore erosion. Brazilian J. Oceanogr. 57, 175-188. https://doi.org/10.1590/s1679-87592009000300002

Pezzi, L. P., Souza, R.B. De, Quadro, M.F.L., 2016a. Uma Revisão dos Processos de Interação Oceano-Atmosfera em 
Regiões de Intenso Gradiente Termal do Oceano Atlântico Sul Baseada em Dados Observacionais. Rev. Bras. Meteorol. 31, 428-453. https://doi.org/10.1590/0102-778631231420150032

Pezzi, L. P., Souza, R.B., Farias, P.C., Acevedo, O., Miller, A.J., 2016b. Air-sea interaction at the Southern Brazilian Continental Shelf: In situ observations. J. Geophys. Res. Ocean. 121, 6671-6695. https://doi.org/10.1002/2016JC011774

Pullen, J., Allard, R., Seo, H., Miller, A.J., Chen, S., Pezzi, L.P., Smith, T., Chu, P., Alves, J., Caldeira, R., 2017. Coupled ocean-atmosphere forecasting at short and medium time scales. $\begin{array}{llll}\text { J. Mar. } & \text { Res. 75, } & \text { 877. }\end{array}$ https://doi.org/10.1357/002224017823523991

Ricchi, A., Miglietta, M., Barbariol, F., Benetazzo, A., Bergamasco, A., Bonaldo, D., Cassardo, C., Falcieri, F., Modugno, G., Russo, A., Sclavo, M., Carniel, S., 2017. Sensitivity of a Mediterranean Tropical-Like Cyclone to Different Model Configurations and Coupling Strategies. Atmosphere (Basel). $\quad 8, \quad 92$. https://doi.org/10.3390/atmos8050092

Saha, S., Moorthi, S., Wu, X., Wang, J., Nadiga, S., Tripp, P., Behringer, D., Hou, Y.-T., Chuang, H., Iredell, M., Ek, M., Meng, J., Yang, R., Mendez, M.P., van den Dool, H., Zhang, Q., Wang, W., Chen, M., Becker, E., 2014. The NCEP Climate Forecast System Version 2. J. Clim. 27, 2185-2208. https://doi.org/10.1175/JCLI-D-12-00823.1

Skamarock, C., Klemp, B., Dudhia, J., Gill, O., Barker, D., Duda, G., Huang, X., Wang, W., Powers, G., 2008. A Description of the Advanced Research WRF Version 3. Boulder, Colorado. https://doi.org/10.5065/D68S4MVH

Sutil, U.A., Pezzi, L.P., Alves, R.C.M., Nunes, A.B., 2019. Ocean-Atmosphere Interactions in an Extratropical Cyclone in the Southwest Atlantic. Anuário do Inst. Geociências - UFRJ 42, 525-535. https://doi.org/10.11137/2019_1_525_535

Tewari, M., Chen, F., Wang, W., Dudhia, J., LeMone, M.A., Mitchell, K., Ek, M., Gayno, G., Wegiel, J., Cuenca, R.H., 2004. Implementation and verification of the unified noah land surface model in the WRF model. Bull. Am. Meteorol. Soc. 2165-2170. https://doi.org/10.1007/s11269-013-0452-7

Vijaya Kumari, K., Karuna Sagar, S., Viswanadhapalli, Y., Dasari, H.P., Bhaskara Rao, S.V., 2019. Role of Planetary Boundary Layer Processes in the Simulation of Tropical Cyclones Over the Bay of Bengal. Pure Appl. Geophys. 176, 951-977. https://doi.org/10.1007/s00024-018-2017-4

Wang, W., Bruyère, C., Duda, M., Dudhia, J., Gill, D., Kavulich, M., Keene, K., Chen, M., Lin, H.-C., Michalakes, J., Rizvi, S., Zhang, X., Berner, J., Ha, S., Fossell, K., 2017. User's Guides for the Advanced Research WRF (ARW) Modeling System, Version 3. https://doi.org/10.5065/D68S4MVH

Zhang, F., Li, M., Ross, A.C., Lee, S.B., Zhang, D.-L., 2017. Sensitivity Analysis of Hurricane Arthur (2014) Storm Surge Forecasts to WRF Physics Parameterizations and Model Configurations. Weather Forecast. 32, 1745-1764. https://doi.org/10.1175/WAF-D-16-0218.1 